\author{
Available online at http://bajas.edu.iq \\ https://doi.org/10.37077/25200860.2019.274 \\ College of Agriculture, University of Basrah
}

\author{
Basrah Journal of \\ Agricultural \\ Sciences
}

ISSN 1814 - 5868 Basrah J. Agric. Sci., 32(Spec. Issue 2): 262-271, 2019

\title{
Effect of Organic compost on Chemical Parameters for Two Varieties of Tomato Plant (Solanum esculentium L.)
}

\author{
Huda H. Aziz, Myson M. Kadim* \& Mohsen A. Desher \\ Department of Horticulture, College of Agriculture, University of Basrah, Iraq \\ *Corresponding author e-mail: maymo6245@gmail.com
}

Received 19 September 2019; Accepted 18 November 2019; Available online 22 November 2019

\begin{abstract}
The experiment conducted during 2018-2019 to study effect of added 15 and 30 t. $^{-1}$ level of three kinds of decomposing organic fertilizers on some chemical properties for two varieties of tomato (Red flower F1 and Waad RZ) in field of agricultural experiments station college of Agriculture, University of Basrah. Results showed a significantly effect of hybrid (Red flower F1) compared with hybrid (Waad RZ) on leaves content of : Total chlorophyll, total $\mathrm{N}$ and total soluble carbohydrate, increased 10.6, 14.39 and $8.84 \%$ respectively. Results showed a significant effect of organic fertilizer especially 15 t.ha ${ }^{-1}$ poultry fertilizer on total chlorophyll and total $\mathrm{N}$ in leaves content with increase of 67.75 and $110.31 \%$ respectively, 30 t.ha $^{-1}$ poultry fertilizer significantly increased of total $\mathrm{P}$ in leaves content increased $143.48 \%$. Decomposing cattle fertilizer with 30 t.ha $^{-1}$ significantly increased of total $\mathrm{K}$ in leaves content with increased $181.30 \%$ also corn residues fertilizer with 30 t.ha $^{-1}$ significantly increased of total soluble carbohydrate with $109.89 \%$. Interaction between experiment factors were significantly effect on total chlorophyll, K and soluble carbohydrate in leaves content. Study also revealed different influences of organic fertilizer as follow: The poultry fertilizer $\left(15 \mathrm{t}^{-h a^{-1}}\right)$ increased the total leaves content of chlorophyll and $\mathrm{N}$ with 67.75 and $110.31 \%$ respectively. While the poultry fertilizer $\left(30 \mathrm{t}^{-h^{-1}}\right.$ ) significantly increased the total leaves content of $\mathrm{P}$ with $143.48 \%$. The decomposed cattle fertilizer $\left(30 \mathrm{t}^{-\mathrm{ha}^{-1}}\right)$ significantly increased the total leaves content of $\mathrm{K}$ with $181.30 \%$. Whereas corn residues $\left(30\right.$ t.ha $\left.^{-1}\right)$ significantly raised the total leaves content of soluble carbohydrate with $109.89 \%$.
\end{abstract}

Key words: Decomposing organic fertilizer, Hybrid tomato, Greenhouses.

\section{Introduction}

Tomato crop (Solanum esculentum L.) is one of an important vegetables crop locally and the entire world, due to its high nutritional value. Where, each $100 \mathrm{gm}$ of tomato fruit contains vitamin A, vitamin B1, vitamin B2, vitamin B3 and vitamin C. Also, calcium, phosphorus, potassium and iron, besides that, tomato contains protein and carbohydrate
(Watt \& Merril, 1963). However, Lycopene content in tomato increasing the importance of consuming it; where, the lycopene is useful to decrease the risk of cancer disease and especially the prostate cancer (Takeoka et al., 2001).

At the present time, many researchers investigated the effect of using organic 
fertilizer on different cultivated plants, especially the tomato which needs high organic matters in the soil to encourage the plants to reach the maximum productivity (Baldock \& Nelson, 2000).

The organic matter of animal residuals is one of best nutrition system that can effect positively on physical, chemical and biological soil properties, however, this type of organic fertilizer supplies nutrients such as $\mathrm{N}, \mathrm{P}$ and $\mathrm{K}$ as well as micronutrients to the soil (Afzel \& Adams, 1992). Al-Amery \& Matlob (2012) found that using of 5\% residuals of cattle, sheep and poultry with $30 \mathrm{~cm}$ deep for tomato, increased the leaves total leaves contents of chlorophyll, N, P and $\mathrm{K}$. This study aimed to select the appropriate kind of organic fertilizers for the two hybrids of tomato cultivated under the southern Iraq.
A greenhouse experiment was conducted during the winter season year 2018-2019 at Researcher Station, College of Agriculture, University of Basrah to study the effect of three kinds of organic fertilizers (Poultry, cattalo and corn residues) in addition to control on some chemical properties of two varieties of tomato hybrids. The greenhouse specifications is $(50 \times 9 \mathrm{~m})$ with $450 \mathrm{~m}^{2}$.

The soil used for this study was classified as: Entisol, typical quartz pasmment according to (Bollago \& Huang,1998). The soil of greenhouse was plowed three times and then settled. A randomized sample was taken from surface $0-30 \mathrm{~cm}$ to determine the physical and chemical properties (Table 1). The analysis had been conducted in the Central Lab., College of Agriculture, University of Basrah.

\section{Materials \& Methods}

Table (1). Some chemicals and physicals properties of soil experimental and irrigation water.

\begin{tabular}{|c|c|c|}
\hline \multicolumn{2}{|c|}{ Properties } & Value \\
\hline \multirow{2}{*}{\multicolumn{2}{|c|}{$\begin{array}{l}\text { pH } \\
\text { E.C. (Ds. } \mathrm{m}^{-1}\end{array}$}} & 7.51 \\
\hline & & 6.50 \\
\hline \multirow{4}{*}{$\begin{array}{l}\text { Soluble captions } \\
\left(\text { Mmol. } .^{-1}\right)\end{array}$} & $\mathrm{Ca}^{+2}$ & 31.14 \\
\hline & $\mathrm{Mg}^{+2}$ & 26.88 \\
\hline & $\mathrm{Na}^{+2}$ & 2.12 \\
\hline & $\mathrm{K}^{+}$ & 1.14 \\
\hline O.M. & & 0.63 \\
\hline \multirow{4}{*}{$\begin{array}{l}\text { Soluble anions } \\
\text { Mmol. } 1^{-1}\end{array}$} & $\mathrm{HCO}^{3}$ & 23.22 \\
\hline & $\mathrm{CO}^{3}$ & - \\
\hline & $\mathrm{SO}_{4}^{-2}$ & 26.32 \\
\hline & $\mathrm{Cl}^{-}$ & 9.66 \\
\hline Total N $\left(\mathrm{g} \cdot \mathrm{kg}^{-1}\right)$ & & 22.2 \\
\hline Available $\mathrm{P}\left(\mathrm{g} \cdot \mathrm{kg}^{-1}\right)$ & & 0.015 \\
\hline C.E.C $\left(\mathrm{g} \cdot \mathrm{kg}^{-1}\right)$ & & 17.33 \\
\hline \multirow{3}{*}{ Soil separated (\%) } & Sand & 12.20 \\
\hline & Silt & 42.7 \\
\hline & Clay & 45.1 \\
\hline \multicolumn{2}{|l|}{ Texture } & Silty clay \\
\hline \multicolumn{2}{|c|}{ Weight soil humidity (\%) } & 6.67 \\
\hline \multicolumn{2}{|c|}{ Soil humidity at field capacity (\%) } & 30.13 \\
\hline \multicolumn{3}{|c|}{ Irrigation water } \\
\hline E.C. Ds. $\mathrm{m}^{-1}$ & & 1.20 \\
\hline $\mathrm{pH}$ & & 7.30 \\
\hline
\end{tabular}




\section{Design of experiment}

Greenhouse soil was plowing with disc plow twice time and divided after levelling to 6 main lines with $30 \mathrm{~cm}$ deep against north wind direction to provide greenhouse plastic damage by wind. Each line was $45 \mathrm{~m}$ divided to seven experiment units as $6 \mathrm{~m}$ for one experiment unit and left out $0.5 \mathrm{~m}$ between experiment unit and other. The distance between lines was $1.30 \mathrm{~m}$ and left out $2.5 \mathrm{~m}$ at front and end of greenhouse as a service area. Temperature was recorded during experiment period (Table 2).

Table (2). Tenth mean of Max. and min. temperature and relative humidity during experiment

\begin{tabular}{lccc}
\hline \multicolumn{1}{c}{ Date } & $\begin{array}{c}\text { Max. } \\
\text { Temperature }\end{array}$ & $\begin{array}{c}\text { Min. } \\
\text { Temperature }\end{array}$ & $\begin{array}{c}\text { Relative } \\
\text { Humidity (\%) }\end{array}$ \\
\hline 1- 10 Sep, 2018 & 45.23 & 27.85 & 20.20 \\
\hline 11- 20 Sep, 2018 & 43.25 & 24.25 & 16.34 \\
\hline 21 - 30 Sep, 2018 & 38.21 & 22.54 & 22.43 \\
\hline 1 - 10 Oct, 2018 & 35.94 & 19.44 & 22.04 \\
\hline 11- 20 Oct, 2018 & 35.26 & 16.85 & 23.42 \\
\hline 21- 30 Oct, 2018 & 30.02 & 15.71 & 33.25 \\
\hline 1-10 Nov, 2018 & 26.87 & 16.27 & 61.05 \\
\hline 11-20 Nov 2018 & 23.89 & 15.61 & 72.46 \\
\hline 21-30 Nov 2018 & 22.39 & 12.64 & 73.58 \\
\hline 1-12 Oct 2018 & 21.63 & 11.27 & 67.22 \\
\hline 11-20 Dec 2018 & 15.70 & 5.79 & 59.77 \\
\hline 21-30 Dec 2018 & 17.17 & 3.48 & 54.41 \\
\hline 1-10 Jan 2019 & 15.60 & 6.68 & 74.46 \\
\hline 11-20 Jan 2019 & 15.09 & 6.01 & 79.25 \\
\hline 21-30 Jan 2019 & 18.27 & 8.30 & 68.56 \\
\hline 1-10 Feb 2019 & 15.79 & 6.64 & 53.27 \\
\hline 11-20 Feb 2019 & 19.85 & 5.27 & 55.43 \\
\hline 21-30 Feb 2019 & 24.60 & 10.31 & 50.28 \\
\hline 1-10 Mar 2019 & 27.80 & 13.23 & 64.55 \\
\hline 11-20 Mar 2019 & 25.01 & 13.30 & 38.63 \\
\hline 21-30 Mar 2019 & 29.08 & 13.59 & 45.41 \\
\hline 1-10 Apr 2019 & 30.83 & 18.93 & 30.47 \\
\hline 11-20 Apr 2019 & 29.12 & 14.23 & \\
\hline 21-30 Apr 2019 & 35.43 & 21.25 & \\
\hline
\end{tabular}

The organic residuals for cattle and poultry were collected from animal field belonging to College of Agriculture, University of Basrah, while the corn plant residuals were collected from private farmers fields. Each kinds of residual were stacked in heap inside the concrete basin $(6 \mathrm{~m} \times 3 \mathrm{~m} \times 1.5 \mathrm{~m})$. Water was added to this heap to wet the organic residuals matters, and then these concrete basins were covered for (12 weeks). Organic residuals were flipping each two weeks to homogenize during the incubation period. At the ending of composting process, sample of each kind of compost was taken to analyse (Table 3). 
Aziz et al.,/ Basrah J. Agric. Sci., 32(Spec. Issue 2): 262-271, 2019

Table (3): Some chemical properties of organic fertilizers used in experiment.

\begin{tabular}{|c|c|c|c|c|c|c|}
\hline \multirow[b]{2}{*}{ Properties } & \multicolumn{2}{|c|}{ Composite } & \multicolumn{2}{|c|}{ Poultry residual } & \multicolumn{2}{|c|}{ Cattle residual } \\
\hline & 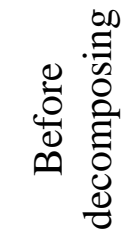 & 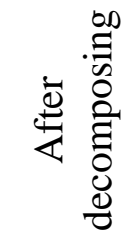 & 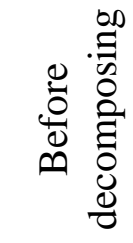 & 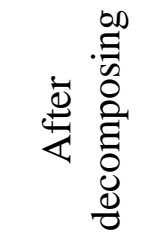 & 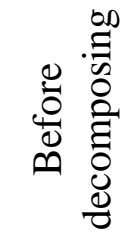 & 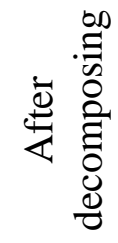 \\
\hline $\mathrm{pH}$ & 7.2 & 7.1 & 6.7 & 7.1 & 6.5 & 6.6 \\
\hline E.C Ds.m ${ }^{-1}$ & 9 & 9.5 & 10.25 & 11 & 2.2 & 2.6 \\
\hline Organic C $\left(\mathrm{g} . \mathrm{kg}^{-1}\right)$ & 226.5 & 236.6 & 311.14 & 327.40 & 66.12 & 74.5 \\
\hline Total N (g.kg $\left.{ }^{-1}\right)$ & 6.5 & 11 & 20.1 & 24.2 & 2.55 & 3.15 \\
\hline Total P $\left(\mathrm{g} \cdot \mathrm{kg}^{-1}\right)$ & 9.81 & 11.14 & 13.4 & 17.16 & 1.6 & 2.11 \\
\hline Total K $\left(\mathrm{g} \cdot \mathrm{kg}^{-1}\right)$ & 7.14 & 4.20 & 5.12 & 3.3 & 2.5 & 1.2 \\
\hline O.M. \% & 142.69 & 149.05 & 196.01 & 206.26 & 41.65 & 46.93 \\
\hline
\end{tabular}

\section{Laboratory Analysis}

Two types of tomato hybrids have been used in this study these are : Red flower R1 from USA and Waad RZ from Netherland Seeds of two hybrids were sown on September/2018 in Styrofoam seedling tray after treated with effective fungicide to avoid having fungal disease in the first place. After the seedling reached appropriate size on the first of October 2018, were moved to the field inside the greenhouse with a distance $50 \mathrm{~cm}$ between each plant. Dripper irrigation had been used for all experimental plants under this study. All agricultural services were applied to the experimental area and plants according to AlMohamedy \& Jasiem 1989). The experiment was conducted as a factorial split plots design according to randomized block with three replicates. The two hybrids of Tomato (Waad and Red flower) considered as a main factor (main-plot), while the organic fertilizer as a secondary factor (Sub-plot) that include 15

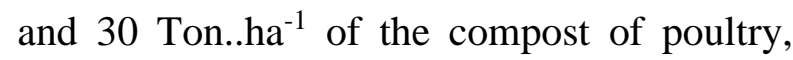
cattle and corn respectively, beside the control treatment.

The result data was analysed statically using the Gen-stat software. The least significant differences test (L.S.D.) at 0.05 has been used according to Al-Rawi \& Khalefallah, (1980).

\section{Chemical analysis}

A five tomato plants were selected randomly from each experimental units to measured chemical properties of plants as follow :

\section{1- Chlorophyll content in leaves (mg. 100gm wet weight ${ }^{-1}$ ):-}

Total chlorophyll was measured in the fourth wet leave by extractable method as describes by Goodwin (1976), according to equation:

$$
\text { Total chlorophyll }(\mathrm{mg} / \mathrm{L})=20.2 \mathrm{D}(645 \mathrm{~nm})+8.02 \mathrm{D}(663 \mathrm{~nm})
$$

where: $\mathrm{D}=$ extractable chlorophyll light density, conversion from $\left(\mathrm{mg} . \mathrm{L}^{-1}\right)$ unit to $\left(\mathrm{mg} .100 \mathrm{~g}^{-1}\right)$ use correlation described by Zaehringer et al. (1974):

$$
\mathrm{mg} .100 \mathrm{gm}^{-1}=\frac{\mathrm{mg} \cdot \mathrm{L}-1}{1000 \mathrm{ml}} \times \frac{100}{\text { sample wiaght }(\mathrm{gm})}
$$




\section{2- Total Nitrogen (\%)}

Selected leaves were dried and digested according to Cresser \& Parsans (1979); while using the Micro-Kjeldahl method to measure the total nitrogen (Jackson, 1958).

\section{3- Total phosphorus in leaves $(\%)$}

Using spectrophotometer on $882 \mathrm{~nm}$ according to Olsen \& Summes (1982).

\section{4- Total potassium in leaves $(\%)$}

Using flame photometer according to AlSahaf (1989).

5- Total soluble carbohydrate in leaves (mg.100gm ${ }^{-1}$ Dry matter)

As stated in the method of Abbas \& Abbas(1992)

\section{Results \& Discussion}

1- Effect of organic matter and varieties on total chlorophyll content in leaves $(\mathrm{mg}$. 100 gm fresh weight $^{-1}$

Data in table (4) explained that the 15 ton. $\mathrm{ha}^{-1}$ of poultry compost increased significantly the chlorophyll content for leaves with a proportion $67.75,0.44,16.40,24.90$ and $22.85 \%$ in compared with other compost treatments. Other compost treatments appeared a significantly rise in chlorophyll content of leaves in contrast with control.

The tomato hybrid (Red flower R1) exhibit significant superiority on leaves content of total chlorophyll in comparison with (Waad RZ) hybrid by $10.60 \%$.

Results also revealed the significant superiority of chlorophyll content (58.05 $\mathrm{mg} .100 \mathrm{gm}^{-1}$ fresh wet) for tomato hybrid (Red flower R1) leaves grown in soil involved with 15 t.ha $^{-1}$ from poultry organic compost.

The Interaction between factors under study, which appeared significantly increasing on total chlorophyll in leaves of tomato plant (Red flower R1 hybrid) that grown in 15 t.ha ${ }^{-1}$ of poultry fertilizer.

\section{2-Effect of organic matter and hybrid on total N (\%)}

Table (5) revealed supremacy effect of hybrid type (Red flower R1) in to nitrogen of leaves by $14.39 \%$.

Table (4): Effect of hybrid and fertilizer treatments and interactions in the total of chlorophyll (mg.100g $\mathrm{g}^{-1}$ fresh wet).

\begin{tabular}{cccc}
\hline $\begin{array}{c}\text { Fertilizer factor effect } \\
(\text { t.ha-1) }\end{array}$ & \multicolumn{2}{c}{ Hybrid effect } & \multirow{2}{*}{ Fertilizer factors mean effect } \\
\cline { 2 - 3 } Control $_{\text {Waad RZ }}$ & Red flower F1 & 32.62 \\
\hline Poultry $\left(15\right.$ t.ha $\left.^{-1}\right)$ & 50.27 & 34.97 & 54.72 \\
\hline Poultry $\left(30\right.$ t.ha $\left.^{-1}\right)$ & 53.23 & 58.05 & 54.48 \\
\hline Cattle $\left(15\right.$ t.ha $\left.^{-1}\right)$ & 64.01 & 48.01 & 47.01 \\
\hline Cattle $\left(30\right.$ t.ha $\left.^{-1}\right)$ & 43.43 & 54.53 & 48.99 \\
\hline $\begin{array}{c}\text { Plant compost } \\
\left(15 \text { t.ha }^{-1}\right)\end{array}$ & 42.72 & 44.89 & 43.81 \\
\hline $\begin{array}{c}\text { Plant compost } \\
(30 \text { t.ha }\end{array}$ & 42.70 & 46.38 & 44.54 \\
\hline Hybrid effect & 44.25 & 48.94 & --- \\
\hline L.S.D. (0.05) & Hybrid & $\begin{array}{c}\text { Fertilizer } \\
\text { treatments }\end{array}$ & Interaction \\
\cline { 2 - 3 } & 0.80 & 1.56 & 2.07 \\
\hline
\end{tabular}


Table (5) also showed that addition of 15 ton/ha of poultry compost increased Effectively of the percentage nitrogen content in tomato leaves $(110.3 \%)$ in compared with other compost treatments as follow: Control (8.42\%), 30 ton. ha ${ }^{-1}(24.62 \%), 15$ ton. ha ${ }^{-1}$ cattle (19.95\%), 30 ton. ha ${ }^{-1}$ cattle $(29.68 \%)$ and $(15,30)$ ton. ha ${ }^{-1}$ corn $(24.62 \%)$. However, result did not detect any significant effect of interaction between two tomato hybrids used in this study.

Table (5): Effect of hybrid and fertilizer treatments and interactions in the total of nitrogen of tomato plant $(\%)$.

\begin{tabular}{cccc}
\hline \multirow{2}{*}{ Fertilizer factor effect $\left(\mathrm{t} . \mathrm{ha}^{-1}\right)$} & \multicolumn{2}{c}{ Hybrid effect } & \multirow{2}{*}{$\begin{array}{c}\text { Fertilizer factors mean } \\
\text { effect }\end{array}$} \\
\cline { 2 - 3 } Control & 3.15 & 3.82 & 3.49 \\
\hline Paad RZ & Red flower F1 & 7.34 \\
\hline Poultry $\left(15\right.$ t.ha $\left.^{-1}\right)$ & 6.78 & 7.89 & 6.77 \\
\hline Poultry $\left(30\right.$ t.ha $\left.^{-1}\right)$ & 6.48 & 7.06 & 5.89 \\
\hline Cattle $\left(15\right.$ t.ha $\left.^{-1}\right)$ & 5.33 & 6.44 & 6.38 \\
\hline Cattle $\left(30\right.$ t.ha $\left.^{-1}\right)$ & 6.00 & 6.77 & 5.66 \\
\hline $\begin{array}{c}\text { Plant compost } \\
\left(15 \text { t.ha }^{-1}\right)\end{array}$ & 5.38 & 5.94 & 5.89 \\
\hline $\begin{array}{c}\text { Plant compost } \\
(30 \text { t.ha })\end{array}$ & 5.33 & 6.44 & ---- \\
\hline Hybrid effect & 5.49 & 6.34 & Interaction \\
\hline L.S.D. (0.05) & Hybrid & $\begin{array}{c}\text { Fertilizer } \\
\text { treatments }\end{array}$ & N.S
\end{tabular}

\section{3- Total P (\%)}

Data of table (6) indicated that addition of 30 ton/ha of poultry compost increased effectively of the percentage phosphorus content in tomato leaves $(143.48 \%)$ in compare with other compost treatments as follow: control $(9.80 \%), 15$ ton/ha poultry $(21.74 \%), 15$ ton/ha cattle $(16.76 \%), 30$ ton/ha cattle $(30.23 \%)$ and $(15,30)$ ton/ha corn $(21.74 \%)$. Result also did not detect any significant effect of interaction between two tomato hybrids.

\section{4- Total K (\%)}

Result in table (7) demonstrated that supplement tomato plants with 30 ton/ha of poultry compost increased effectively of the percentage potassium content in their leaves
(181.30\%) in compare with other compost organic composts used in this study as follow: control (23.13\%), 15 t.ha ${ }^{-1}$ poultry $(18.08 \%)$, 15 t.ha $^{-1}$ cattle $(16.49 \%), 30$ t.ha ${ }^{-1}$ cattle $(119.68 \%)$ and (15 and 30) t.ha-1 corn (35.95\%). Result also did not detect any significant effect of interaction between two tomato hybrids.

Result also showed a significantly raised of total potassium content with $7.24 \%$ for the (Red flower R1) hybrid leaves plants grown in soil that have 30 t.ha ${ }^{-1}$ of cattalo compost (Table 7). 
Table (6). Effect of hybrid and fertilizer treatments and interactions in the total of phosphor of tomato plant (\%)

\begin{tabular}{cccc}
\hline $\begin{array}{c}\text { Fertilizer factor effect } \\
\left(\text { t.ha }{ }^{-1}\right)\end{array}$ & \multicolumn{2}{c}{ Hybrid effect } & $\begin{array}{c}\text { Fertilizer factors mean } \\
\text { effect }\end{array}$ \\
\cline { 2 - 3 } Control $^{\text {Waad RZ }}$ & 0.24 & Red flower F1 & 0.23 \\
\hline Poultry $\left(15\right.$ t.ha $\left.^{-1}\right)$ & 0.51 & 0.23 & 0.51 \\
\hline Poultry $\left(30\right.$ t.ha $\left.^{-1}\right)$ & 0.57 & 0.55 & 0.56 \\
\hline${\text { Cattle }\left(15 \text { t.ha }^{-1}\right)}_{\text {Cattle }\left(30 \text { t.ha }^{-1}\right)}$ & 0.45 & 0.47 & 0.46 \\
\hline $\begin{array}{c}\text { Plant compost } \\
\left(15 \text { t.ha }^{-1}\right)\end{array}$ & 0.47 & 0.48 & 0.48 \\
\hline $\begin{array}{c}\text { Plant compost } \\
\left(30 \text { t.ha }^{-1}\right)\end{array}$ & 0.42 & 0.44 & 0.43 \\
\hline Hybrid effect & 0.46 & 0.47 & 0.46 \\
\hline L.S.D. $(0.05)$ & Hybrid & $\begin{array}{c}\text { Fertilizer } \\
\text { treatments }\end{array}$ & Interaction \\
\cline { 2 - 3 } & N.S & 0.02 & N.S
\end{tabular}

Table (7): Effect of hybrid and fertilizer treatments and interactions in the total of potassium of tomato plant $(\%)$.

\begin{tabular}{cccc}
\hline $\begin{array}{c}\text { Fertilizer factor effect } \\
\left(\text { t.ha }{ }^{-1}\right)\end{array}$ & \multicolumn{2}{c}{ Hybrid effect } & $\begin{array}{c}\text { Fertilizer factors mean } \\
\text { effect }\end{array}$ \\
\cline { 2 - 3 } Control $^{-1}$ & Waad RZ & Red flower F1 & 2.46 \\
\hline Poultry $\left(15\right.$ t.ha $\left.^{-1}\right)$ & 6.63 & 2.36 & 5.62 \\
\hline Poultry $\left(30\right.$ t.ha $\left.^{-1}\right)$ & 6.05 & 4.61 & 5.86 \\
\hline${\text { Cattle }\left(15 \text { t.ha }^{-1}\right)}_{\text {Cattle }\left(30 \text { t.ha }^{-1}\right)}$ & 5.83 & 5.68 & 5.94 \\
\hline $\begin{array}{c}\text { Plant compost } \\
\left(15 \text { t.ha }^{-1}\right)\end{array}$ & 6.61 & 7.24 & 6.92 \\
\hline $\begin{array}{c}\text { Plant compost } \\
\left(30 \text { t.ha }^{-1}\right)\end{array}$ & 3.24 & 3.06 & 3.15 \\
\hline Hybrid effect & 5.86 & 4.32 & 5.09 \\
\hline L.S.D. $(0.05)$ & Hybrid & $\begin{array}{c}\text { Fertilizer } \\
\text { treatments }\end{array}$ & Interaction \\
\cline { 2 - 3 } & N.S & 0.47 & 1.14 \\
\hline
\end{tabular}

5- Total soluble carbohydrate (mg. $\mathrm{gm}^{-1}$ Dry matter )

Total soluble carbohydrate content of tomato hybrid (Waad RZ) leaves presented in table (8) showed increased with $8.84 \%$. Result in table (8) revealed that tomato plants grown on 30 t.ha $^{-1}$ of corn compost fertilizer increased effectively the total soluble carbohydrate content in their leaves $(109.89 \%)$ in compare with other organic composts used in this study as follow: control $(38.33 \%), 15$ ton. ha $^{-1}$ poultry $(21.23 \%), 30$ ton. ha ${ }^{-1}(30.15 \%), 15$ ton. ha ${ }^{-1}$ cattle $(25.74 \%), 30$ ton. ha ${ }^{-1}$ cattle and 15 ton. ha $^{-1}$ corn $(1.66 \%)$. Result also demonstrated a significantly hike of total soluble carbohydrate content in the leaves 
$523.9 \mathrm{mg}$. $\mathrm{gm}^{-1}$ D.W. for tomato hybrid (Waad RZ) grown in soil that have 30 t.ha ${ }^{-1}$ of plant compost (Table 8).

Data in tables (4, 7 and 8 ) showed significantly affect between two tomato hybrid in the total leaves content of chlorophyll, potassium and soluble carbohydrate. Variance in these proprieties may be due to the genetic variability between the two hybrids in addition to response to the climate conditions. The results agreed with results of Al-Abadi (2012).

Data in tables (4, 5 and 6) showed increasing in nitrogen and phosphorus, when plant grown in soil contain poultry fertilizer. The organic matter considered as an important factor for the minerals availability in soil solution, and this help the plant to increase the nutrients absorption . (Tisdal et al., 1995).

\section{Table (8). Effect of hybrid and fertilizer treatments and interactions in the total of soluble carbohydrates (mg. gm ${ }^{-1}$ dry matter)}

\begin{tabular}{cccc}
\hline $\begin{array}{c}\text { Fertilizer factor effect } \\
\left(\text { t.ha }{ }^{-1}\right)\end{array}$ & \multicolumn{2}{c}{ Hybrid effect } & $\begin{array}{c}\text { Fertilizer factors mean } \\
\text { effect }\end{array}$ \\
\cline { 2 - 3 } Control $^{-1}$ & 218.9 & 276.3 & 247.6 \\
\hline Poultry $\left(15\right.$ t.ha $\left.^{-1}\right)$ & 423.1 & 328.3 & 375.7 \\
\hline Poultry $\left(30\right.$ t.ha $\left.^{-1}\right)$ & 459.9 & 397.5 & 428.7 \\
\hline Cattle $\left(15\right.$ t.ha $\left.^{-1}\right)$ & 312.2 & 486.3 & 399.3 \\
\hline${\text { Cattle }\left(30 \text { t.ha }^{-1}\right)}^{\text {Plant compost }}$ & 323.8 & 5.2 .9 & 413.3 \\
\hline $\begin{array}{c}\left(15 \text { t.ha }^{-1}\right) \\
\text { Plant compost } \\
\left(30 \text { t.ha }^{-1}\right)\end{array}$ & 519.6 & 502.9 & 511.2 \\
\hline Hybrid effect & 515.4 & 523.9 & 519.7 \\
\hline L.S.D. $(0.05)$ & 396.1 & 431.1 & --- \\
\hline & Hybrid & $\begin{array}{c}\text { Fertilizer } \\
\text { treatments }\end{array}$ & Interaction \\
\hline
\end{tabular}

Al-Amery \& Matlob (2012) reported that addition of poultry compost improved the chemical properties of the soil through increased nitrogen rates to soil solution, and thus in turn increased of nitrogen accumulation in plant tissue. On the other hand, the high Nitrogen rate increment the formation of chlorophyll and amino acids in the chloroplast (Gutierrez -Micelli et al., 2007). Also, Peter \& Reson (2005) confirmed that the in leaves.

The addition of organic fertilizer leads to raise the phosphorus rate in leaf through percentage of Nitrogen concentrated increased the uptake it by plant. The increasing the availability of phosphorus in the soil, may due to increase the solubility and release of phosphate in the organic compost (AlArkawazi, 2000). This results agreed with results of Ewulo et al. (2008) on tomato plant.

Data in table (7) displayed that addition 30 t.ha ${ }^{-1}$ of decomposing cow fertilizer cause a high increasing in potassium percentage in tomato leaves. The reason may due to the elements supplements from residuals fertilizer and increased its availability in soil solution, that easily uptake by plants (Table 3 ); beside 
decreased leaching nutrient element from soil solution due to chelating combination of organic acid from analysis organic matter (Zink \& Allen, 1998; Meena et al., 2007).

Table (8) exhibited that addition of corn compost affect a significantly increasing in total soluble carbohydrate in tomato leaves, this may be due to role of corn compost to supply soil solution with elements and especially the macronutrients. So that increased absorption of plants to these elements. These elements play an active role in reactive enzymes in photosynthesis process and causing the increment of total soluble carbohydrate in tomato leaves (Al-Shahwani, 2006). These results are in line with the observations of Al-Amery \& Matlob (2012).

\section{Conclusions}

We conclude that addition of organic fertilizers (poultry fertilizer at rate 15 t.ha ${ }^{-1}$ or cowing manure compost with a rate 30t.ha-1) led to improve all chemical characteristics of both tomato hybrids under study. Also present investigation found that the chemical characteristics of both tomato hybrids (Red flower F1 and Waad RZand) are significantly different. However, the study recommended searching a new tomato hybrid more suitable to environmental conditions in Basrah.

\section{Acknowledgements}

The authors would like to thanks staff of Department of Horticulture and Land Scape for support the work.

\section{References}

Abbas, M.F. \& Abbas, M.Ch. (1992). Care and Storage Fruit and Vegetables, Practical Methodology. Coll. Agric., Univ. Basrah. High. Educ. Sci. Res.: 153pp. (In Arabic).

Al-Abadi, M.J.M. (2012). Effect of spraying of common liquorice extract and yeast solution on some characters of growth and yield to hybrids of tomato plant (Lycopersicon esculentim Mill). M. Sc. Thesis. Coll. Agric.. Univ. Al-Muthana: 182pp. (In Arabic).

Afzal, M. \& Adams, W.A. (1992). Heterogeneity of soil mineral nitrogen in pasture grazed by cattle. Soil Sci. Soc. Am. J., 56(4): 1160-1166.

Al-Amery, N.J.K. \& Matlob, A.N. (2012). Effect of organic fertilizer on growth and yield of tomato plant, under warmed greenhouses. Euphrates Agri. Sci., 4(3): 21-38. (In Arabic).

Al-Arkawazi, J.A.S. (2000). Effect of organic and phosphorus fertilizers on phosphorus availability at different stages of tomato plants growth. M. Sc. Thesis, Coll. Agric. Univ. Baghdad: 188pp. (In Arabic).

Al-Mohamadey, F. M. \& Jasiem, A.J. (1989). Production Vegetables. Dar Al-Hikma. Baghdad Univ. Min. High. Educ. Sci. Res.: 232pp. (In Arabic).

Al-Rawi, K.M. \& Khalfalah, A.M. (1980). Design and analysis agricultural experiments. Dar Al-Kutb for Publishing and Distribution. Univ. Mosul: 488pp. (In Arabic).

Al-Sahaf, F.H. (1989). Practical Plant Nutrition. Ministry of Higher Education and Scientific Research. Univ. Baghdad, Biet. Al-Hikma: 251pp. (In Arabic).

Al-Shahwani, A.W.R. (2006). Effect of water salinity irrigation on growth and yield of potato Solanum tuberosum L. and alleviation ways in it. Ph. D. Thesis, Coll. Agric. Univ. Baghdad: 173pp. (In Arabic).

Baldock, J.A. \& Nelson, P.N. (2000). Soil Organic Matter: 25-48. In Summer, M.E. 
(Ed.). Hand Book of Soil Science. C.R.C. Press: 2110pp.

Bollago, J.M.J. \& Huang, P.M. (1998). Soil organic matter. Adv. Agron., 63(5): 229238.

Cresser, M.S. \& Parsons, J.W. (1979). Sulphric-perchloric acid of digestion of plant material for determination of nitrogen phosphorus, potassium, calcium and magnesium. Anal. Chem. Acta, 109: 431436

Ewula, B.S.; Djeniyi, S.O. \& Akanni, D.A.A. (2008). Effect of poultry manure on selected soil physical and chemical properties, growth and nutrient status of tomato .Afr. J. Agric. Res., 3(9): 612-616.

Goodwin, T.W. (1976). Chemistry and Biochemistry of Plant Pigment. $2^{\text {nd }}$ ed. Academic Press, London: 373pp.

Gutierrez-Micelli, F.A.; Santiago-Borraz, J.; Montes-Molina, A.; Nafate, C.C.; AbudArchila, M.; Oliva-Laven, A.M.; RinconRosales, R. \& Dendooven, L. (2007). Vermin composting as a soil yield and fruit supplement to improve growth, yield and fruit quality of tomato (Lycopersicon esculentim Mill). Biol. Tech., 98(15): 2781-2787.

Hao, X.H.; Liu, S.; Wu, J.S.; Hu, R.G.; Tong, C.L. \& Su, Y.Y. (2008). Effect of longterm application of inorganic fertilizer and organic amendments an soil organic matter and microbial in three subtropical soils. Nutr. Cycl. Agroecosyst., 81(1): 17-24.

Jackson, M.L. (1958). Soil Chemical Analysis. Prentice Tall Inc. Englewood Cliff, N. J.: 521pp.Meena, S.; Senthilvalavn, P.; Malarkodi, M. \& Kaleeswari, R.K. (2007). Residual effect of organic manures in sunflower-assessment using rodeo trance Technique Res. J. Agric. Biol. Sci., 3(5): 377-379.

Olsen, S.K. \& Sommers, L.E. (1982). Phosphorus. 403-427. In Page, A.L.; Miller, R.H. \& Heeney, D.R. (Eds.). Methods of Soil Analysis. Am. Agron. Inc. Madison, Wisconsin: $1572 \mathrm{pp}$.

Peter, M.B. \& Reson, C.J. (2005). Nutrient cycling and maintaining soil fertility in fruit and vegetable crop systems. Dept. soil, water and Climate-Univ. Minnesota. M1193. 2005.

Takeoka, G.R.; Dao, L.; Flessa, S.; Gillespie, D.M.; Jewell, W.T.; Huebner, B.; Bertow, D. \& Ebeler, S.E. (2001). Processing effects on lycopeme content and antioxidant activity of tomatoes. J. Agric. Food. Chem., 49(8): 3713-3717.

Tisdal, S.L.; Nelson, W.L.; Beaton, J.D. \& Havlin, L.L. (1995). Soil Fertility and Fertilizer. $5^{\text {th }}$ edn. Prentice-Hall of India, New Delhi: 684pp.

Watt, B.K. \& Merrill, A.L. (1963). Composition of food, processed and prepared. U. S. Department of Agriculture. Agriculture hand Book 8.: 190pp.

Zaehringer, M.V.; Davis, K.R. \& Dean, L.L. (1974). Persistent green color snap beans (Phaseolns vnlgaris) color related constituents and quality of cooked fresh beans. J. Am. Soc. Sci., 99: 89-92.

Zink, J.A. \& Allen, M.F. (1998). The effects of organic amendment on the restoration of a disturbed coastal sage scrub habitat. Restoration Ecol., 6(1): 52-58. 